\title{
EMOTIVENESS AS A REFLECTION OF EMOTIONALITY AT THE LINGUISTIC LEVEL
}

\author{
Dilnoza Nurmakhamatovna Abduvakhabova
}

Tashkent University Of Information Technologies Named After Muhammad Al-Khwarizmi, Uzbekistan

\section{ABSTRACT}

This article is devoted to the category of emotiveness which has been one of the most debatable problems in linguistics and the different views of some linguists about it. Considering the category of emotiveness as a linguistic aspect of emotionality, various linguists choose a different approach to the concept of emotiveness. Furthermore, the article represents the correlation of the category of emotionality with the categories of expressiveness, modality and evaluation.

KEYWORDS: - Emotiveness, emotionality, expressiveness, modality, evaluation, pragmatics, linguistics, philologists.

\section{INTRODUCTION}

Over the past decades, the problem of emotiveness has been one of the most discussed in anthropocentric linguistics. As experts characterize the current situation in the science of language, "linguistics, which has put the personality of a person at the center of his scientific interests, uses the principle that scientific objects as the main research principle should be studied primarily by their role for the person, by their purpose in his life, by their functions for the development of the human personality and its improvement "(Kubryakova, 1988). Emotions and various ways of expressing them from time immemorial have been one of the most intriguing questions that have ever arisen in the process of human self-knowledge, therefore, increased interest in the verbal design of emotions does not cause surprise. However, despite the close attention that linguists have been devoting to the problem of emotiveness for more than twenty years, many of its aspects are still debatable.

\section{Methodology}

Considering the category of emotiveness as a linguistic aspect of emotionality, it should be considered that, in the framework of this definition, various linguists choose a different approach to the concept of emotiveness. If for such researchers as V.I. Shakhovsky, Sh. Bally, V.N. Telia, etc. emotiveness is primarily a property of the semantics of individual language units, then for others (I.V. Arnold; T. Van Dyck; K.A. Dolinin; I.I. Sandomirskaya) it is primarily a property of semantic associations of linguistic units, that is, text. It is noteworthy, however, that

most linguists unanimously recognize functionality of the category of emotiveness, and the difference in concepts is determined, more likely, by the concentration of one or another researcher on a particular function of this category than by the negation of others. 
CURRENT RESEARCH JOURNAL OF PHILOLOGICAL SCIENCES 2(7): 25-31,

May 2021 DOI: https://doi.org/10.37547/philological-crjps-02-07-07

ISSN 2767-3758

(C)2021 Master Journals

\section{Crossref do) 8 Google}

Accepted24thJuly, 2021 \& Published 29thJuly, 2021

So, some philologists focus not on the expressive, but on the incentive aspect of emotiveness, i.e. they are interested in emotiveness not just as a reflection of the sensory sphere of the information generator (for example, a writer or speaker), but as a means of exciting certain feelings and emotions at the recipient of information (for example, the reader or listener). In other words, they understand as a certain experience of the subject, transformed by consciousness into linguistic symbols and causing an emotional reaction in the recipient (Bally 1961; Telia 1986) or as "a linguistic category that implies only those emotional phenomena that are associated with the expression of an emotionally-valued attitude, which are aimed at creating an emotional resonance in the listener "(Sandomirskaya 1991, p. 114). Linguists who consider emotion as a characteristic of the text tend to a similar approach (T.A. Van Dyck 1972 (Dijk 1972) V.A. Kukharenko 1988; V.A. Maslova 1991; II Sandomirskaya 1991; V.N. Telia 1991 (a); 1991 (6)).

Other researchers primarily analyze the expressive aspect of emotiveness, i.e. emotiveness interests them at the same time as a certain mechanism of processing the subject's feelings and emotions into linguistic information (psycholinguistic and neuro psycholinguistic aspect) and as a set of linguistic methods and means of displaying these feelings and emotions (linguistic aspect), regardless of whether this mapping is directed at any the recipient. In particular, A.B. Kunin interprets emotiveness as "emotionality in linguistic refraction, that is, a sensory assessment of an object, as an expression of linguistic and verbal means of human feelings, moods, experiences" (Kunin 1986, p. 153).

V.I. Shakhovsky takes an intermediate position, although he is more inclined to the opinion expressed by A.B. Kunin: "The speaker, expressing his emotion, first of all expresses his attitude to the subject of speech, and does not at all seek to cause any emotion in the listener. The primary function of emotive words is therefore emotional self-expression. Whether it affects the listener or not is not always relevant for the speaker, since pragmatics are not always included in his intention. But, of course, the emotive words have a function of influence, it is presupposed by their emotive meaning and is realized when its purpose is present when expressing emotions "(Shakhovsky, 1987, p. 52).

V.I. Shakhovsky also considers the designating or naming aspect of emotiveness, saying that emotion is not only a form of reflection of reality (namely, a reflection of attitude to the world), but itself is an object of reflection for the language and therefore is recorded in the language: joy , disparagement, despondency, fear, etc. (Shakhovsky 1987, p. 94). V. I. Shakhovsky, however, notes that the names of emotions in the language are already metaemotions, and not the emotions

themselves: this is their conceptual designation. And if the word only means, calls emotion, then it is not emotive (ibid.). The semantics of such a word are the images of different feelings called by it, and not the feelings themselves (Ibraev 1981, p.23).

\section{Discussion}

As 0.A. Levin emphasizes in his study, "it is clear that the differences in the approach to emotiveness among different researchers are due to the material to which their attention is directed and, if lexical units are considered, their ability to reinforce in their semantics an indication of the emotional attitude to the object of the nomination comes to the fore, and if the text is analyzed, then the emotional empathy that it causes [...] General integral study of the category of emotiveness, it seems, should take 
CURRENT RESEARCH JOURNAL OF PHILOLOGICAL SCIENCES 2(7): 25-31,

May 2021 DOI: https://doi.org/10.37547/philological-crjps-02-07-07

ISSN 2767-3758

(C)2021 Master Journals

\section{Crossref do) 8 Google}

Accepted24thJuly, 2021 \& Published 29thJuly, 2021

into account both aspects "(Levy) for 2004, p.10). Based on this statement, O.A. Levin identifies two main types of emotional manifestations in a literary text: a) the author's vision of the character's emotions, their description and expression; b) author's emotiveness, that is, the emotional involvement of the author of a work of art in the events he describes (Levin 2004, p.10).

We would like to develop the thought of O.A. Levin, suggesting that the author's vision of the emotions of the character (a) is divided into at least five types:

1) the author's direct description of the character's emotions

That really pissed him off, although he felt he managed to disguise

his annoyance pretty well... (N. Hornby. About a Boy)

2) the author's indirect description of the character's emotions (carried out not through a specific indication of a particular emotion, but through a description of the signs of manifestation of this emotion (behavior, character appearance, etc.))

And as if the sun had gone out of the game, Lo slackened and slowly got up

ignoring the ball that the terrier placed before her. (V. Nabokov. Lolita)

3) a direct expression of the character's emotions through his discourse (the character's specific indication of the emotion he is experiencing)

She hugged him: "O Harry, I'm so excited. I can't tell you."

\section{(H. Selby. Requiem for a Dream)}

4) indirect expression of the character's emotions through his discourse (lexical, syntactic and morphological signs of a particular emotion in the character's speech (suffixes of subjective attitudes, epithets, comparisons, repetitions, exclamations, etc.))

"Bastards. Suckmothers. Smug, s muggy, smuggery smugger s."

(S. Fry. Making History)

5) indirect expression of the character's emotions through the character's description of the environment, the current situation, or other characters

"It was the same child - the same frail, honeyhued shoulders, the same silky supple bare back, the same chestnut head of hair." (V. Nabokov. Lolita)

In addition to the five types indicated, in our opinion, we can also distinguish the sixth, intermediate type, which in a sense combines the two indicated by O.A. Levin, the type of emotional manifestation in a literary text - the author's vision of the character's emotions and author's emotional involvement in the events he describes

6) Indirect expression by the author of the emotions of one or more characters through a description of the situation or circumstances that accompany this or that emotion or cause it

There was a pregnant silence. (J. Fowls. The French Lieutenant's Woman);

It is noteworthy that situational or contextual emotives (according to our observations) are most often found in types' 5 and 6 (a vivid example of such an emotive is the word "pregnant" in the last example).

The debatable aspects of emotiveness as a phenomenon can also include problems of emotive meaning and the emotive component (or connotation) of lexical semantics.

However, some researchers (Shakhovsky 1987, p.60) believe that the function of the word is used to express emotions, and not its meaning. This function is determined, in his opinion, by 
CURRENT RESEARCH JOURNAL OF PHILOLOGICAL SCIENCES 2(7): 25-31,

May 2021 DOI: https://doi.org/10.37547/philological-crjps-02-07-07

ISSN 2767-3758

(C)2021 Master Journals

\section{Crossref do) 8 Google}

Accepted24thJuly, 2021 \& Published 29thJuly, 2021

the context and conditions of communication (from this point of view, we partly proceed from the present study when analyzing emotive expressions in English literature and how to translate them into another language, although we prefer the term "word function" to be " the speaker's attitude to the word ", which is traced in the literature from the context, and is marked at the level of live speech). Stevenson and Britton define the emotive meaning as the potential ability of a word to be the "causative agent" of any emotion (Stevenson; quoted from Shakhovsky 1987). Such an interpretation is objectionable to V.I. Shakhovsky, who emphasizes that in speech almost any rational word can cause emotions due to situational, syntactic and prosodic factors, but this does not mean at all that it achieves this with its emotive meaning (Shakhovsky 1987, p. 61). I.V. Arnold, unlike Stephenson and Britton, considers the emotional meaning not as the ability of a word to evoke any emotion, but as the property of a word or its variant to express some emotion or feeling (Arnold 1981, p. 106). "The emotional component arises on the basis of the subjectlogical" (Arnold 1981, p. 106), she explains. I.V. Arnold and some other linguists, such as I.I. Sandomirskaya and V.N. Telia are inclined to the point of view that the emotive meaning of a word is a component of its connotation, while connotation is a multilevel semantic system represented by a whole set of such components (Arnold 1981; Sandomirskaya 1991; Telia 1986). V.I. Shakhovsky, on the contrary, believes that the emotive meaning is all the semantic content of a certain category of emotive words affectives, and connotation is only a segment, or "that component of the semantics of a linguistic unit, with the help of which the speaker's emotional state and the relation to the addressee, object and the subject of speech, the situation in which this verbal communication takes place and which are called in the logical-objective meaning of this unit"(Shakhovsky 1987 p. 68).

Based on the difference in approaches, we can conclude that the category of emotiveness is a multi-level concept, implying two different, but inextricably related phenomena in linguistic literature - the emotion of linguistic units carrying an emotive "charge" in their semantics, and the emotiveness of the text is a text category aimed at creating the emotional background of the work of art and causing the emotional impact on the reader (Levin 2004, p. 11). How correctly observes O.A. Levina: "The interconnection of these phenomena is manifested, at least, in the fact that linguistic emotive means are one of the most important combat elements that form the textual category of emotiveness" (Levin 2004, p.l 1).

According to some philologists, any distinction between the concepts of emotiveness and expressiveness is not mandatory or scientifically justified - they consider the words "expressiveness" and "emotiveness" to be absolutely equivalent, meaning the same language sphere (Bally 1961; Vinogradov 1947; Zvegintsev 1957 ; Reformed 1977).

V.I. Shakhovsky emphasizes the importance of distinguishing between emotiveness and expressiveness, linking the emotiveness of the utterance primarily with the realization of an emotional assessment, and expressiveness with purposeful amplification of the utterance (expressive, emotive or other means) designed for a specific reaction of the addressee, i.e. on the desired effect of what was said (Shakhovsky 1975, p.21; 1987, p.59). Also, V.I. Shakhovsky explains the need to distinguish differences between the emotive and expressive functions of a word, considering it an indispensable condition for understanding the different functions of different semantic types of words, and in particular the differentiation of emotives and expressives in the vocabulary cases of all 
CURRENT RESEARCH JOURNAL OF PHILOLOGICAL SCIENCES 2(7): 25-31,

May 2021 DOI: https://doi.org/10.37547/philological-crjps-02-07-07

ISSN 2767-3758

(C)2021 Master Journals

\section{Crossref do) 8 Google}

Accepted24thJuly, 2021 \& Published 29thJuly, 2021

languages, which, in turn, is an important condition for understanding text-forming functions and their interactions in various types of texts (Shakhovsky 1987, p. 59).

H. Grishina (1988), V.N. Telia (1991 (b)) and I.I. Sandomierz (1991) partly shares the position of V.I. Shakhovsky, considering expressiveness, first of all, as a pragmatic aspect of emotiveness, i.e. not only as a connecting link between the designation of the object of the surrounding reality and the emotional perception of this object by a single subject, but as a means of transmitting this perception to some addressee. In the framework of this approach, "expressiveness of speech means its nonneutrality, deautomatization, which make speech unusual, and thereby expressiveness, due to the fact that the signal transmitted by the linguistic expression is amplified and thereby isolated from the general flow or due to an unusual stylistic the use of linguistic means, either by intensifying the quantitative or qualitative aspects of the signified, or as a result of the perception of an associative-shaped representation, excited by this expression, and serving as an incentive for a positive or negative reaction of the recipient "(Telia in 1991 (b), p.7).

Based on the above reasoning V.I. Shakhovsky (see p.24 of this study), it can be concluded that an emotive statement is not always expressive (since its purpose is not always to influence the recipient), at the same time, "expression in the language is not always emotional" , that is, "expression is not always and not only created with the help of emotionality, it can be realized through categories such as appraisal, incentive modality and, in general, through the expression of emotions in humans, which is facilitated by paths and figures echi. In this case, expression also acts as a secondary phenomenon, but no longer on the basis of the emotional, it is not related to it ". Taking into account the opinions of most experts, we consider the following conclusion to be legitimate: emotiveness and expressiveness should be considered as two capable of complementing each other, but not related by the relationship of the part and the whole and mutually non-deterministic categories (i.e., an emotive utterance may or may not be expressive, as well as expressive statement may or may not be emotive). Moreover, the expressiveness of the utterance is associated with the emotional self-expression of the subject and is independent of the presence or absence of the addressee, while expressiveness is always associated with the intellectual intention to convince the addressee of something (Shakhovsky 1975, p.21).

The evaluation category is considered by many researchers in close connection with the category of emotiveness. According to O.S. Akhmanova evaluation is "the speaker's judgment, his attitude - approval or disapproval, desire, encouragement, etc. - as one of the main parts of the stylistic connotation ", while the emotive / emotional is considered by the same researcher as" relating to the expression of feelings, moods, subjective attitudes "(Akhmanova 2005). As can be seen from the definitions, the two categories are really quite close, but there are differences between them, noted by a number of linguists (Shakhovsky 1988; Bally 1961; Telia (1986; 1991 (a); 1991 (b); Sandomirskaya 1991 and others). If emotiveness always implies the emotional attitude of the subject to the object, then evaluation can be "free" of emotions. Researchers distinguish between two types of evaluation: rational - based on the logical judgments and conclusions of the individual about objective reality, and emotional, in which the emotional attitude of the individual to the subject is added to the logical judgment (Belyaevskaya 1987; Shakhovsky 1988; Sandomirskaya 1991).

In the first case (with a purely logical judgment), the evaluation, in our opinion, approaches the 
CURRENT RESEARCH JOURNAL OF PHILOLOGICAL SCIENCES 2(7): 25-31,

May 2021 DOI: https://doi.org/10.37547/philological-crjps-02-07-07

ISSN 2767-3758

(C)2021 Master Journals

\section{Crossref do) 8 Google}

Accepted24thJuly, 2021 \& Published 29thJuly, 2021

category of modality, understood as "a conceptual category with the meaning of the speaker's attitude to the content of the statement and the relation of the content of the statement to reality (definition by O.S. Akhmanova), in the second case (when a subjective-emotional attitude is superimposed on the logical perception), the category of evaluation is "combined" with the category of emotiveness.

Thus, as an example of evaluations that are close to modality, one can cite such statements as: "This should be right", "It is not a very serious kind of conversation", "There are only highly professional players in this team", "Only carefully selected personnel are allowed to participate in the project," "Such behavior in a public place is unacceptable," etc. Examples of evaluative combined with emotiveness include phrases such as: "They're just a bunch of morons," "He is the most charming person in the world," "This book is fascinating," "She's just lovely." It is God who knows what it is, "You behave ugly," etc.

\section{Conclusion}

Summing up the consideration of the correlation of categories of emotiveness, expressiveness, modality and evaluation, we would like to join O.A. Levin, who believes that "to clarify the nature of the interaction between [these categories], it should be kept in mind that emotion, modality,

and evaluation are more likely than expressiveness to the speaker's plan. Therefore, we can say that the distinguished categories are not isolated or overlapping linguistic subsystems, but views of one phenomenon.

\section{References}

1. Batalova T.M. Associative and connotative connections in a literary text as a means of creating imagery // Linguistic aspects of imagery. -M.,1981.-Vol.174.- P.75-82.

2. Belyaevskaya E.G. The semantics of the word. - M.: Higher School, 1987. -128 p.

3. Vinogradov V.V. Russian language. Grammatical doctrine of the word.-M., 1947$300 \mathrm{p}$.

4. Vinogradov V.V. On the category of modality and modal words in Russian // Selected Works. Research on Russian grammar. - M .: Nauka, 1975 .-- P. 53-87.

5. Donskova O.A. Means of expressing the category of modality and dramatic text (based on Anglo-American drama of the 20th century): Dis. ... cand. filol. sciences. M., 1982. - $184 \mathrm{p}$.

6. Galperin I.R. Text as an object of linguistic research. -M.: Science, 1981.-138 p.

7. Gordeliy Z.P. The modal structure of the text of an essay (based on English literary criticism of the 17th-20th centuries): Dis. . Cand. filol. sciences. - M., 1991 -192 p.

8. Kubryakova E.S. The role of word formation in the formation of the linguistic picture of the world // The role of the human factor in the language: language and picture of the world. USSR Academy of Sciences: Institute of Linguistics. - M .: Nauka, 1988.-P. 141172.

9. Levina O.A. Representation of the emotional state of characters in an English literary text: linguistic and cognitive aspects. Dis. ... Ph.D. sciences. - M., 1999 .-- 481 p.

10. Sandomirskaya I.I. The emotive component in the meaning of the verb (on the material of verbs denoting behavior) // The human factor in the language: Language mechanisms of expressivity. - M :: Nauka, 1991.- P. 114-136.

11. Shakhovsky V.I. The problem of 
CURRENT RESEARCH JOURNAL OF PHILOLOGICAL SCIENCES 2(7): 25-31,

May 2021 DOI: https://doi.org/10.37547/philological-crjps-02-07-07

ISSN 2767-3758

(C)2021 Master Journals

Crossref dof 81 Google

Accepted24thJuly, 2021 \& Published 29thJuly, 2021

distinguishing between expressivity and 'emotiveness as a semantic category of linguostylistics // Problems of semasiology and linguostylistics. - Ryazan, 1975, - Vol. 2. P. 3-25.

12. Shakhovsky V.I. About methods of emotive nomination // Semantic-systemic relations in the vocabulary of Germanic and Romance languages. - Volgograd, 1981.P. 160.

13. Shakhovsky V.I. The emotive component of meaning and methods for its description: Textbook. pos. to the special course. Volgograd, 1983.- 93 p. Shvedova 1970

14. Telia V.N. The connotative aspect of the semantics of nominative units. Institute of Linguistics. - M .: Nauka, 1986 .-- 143 p.

15. Zmievskaya H.A. Subjective-evaluative modality in a literary text // Sat. scientific tr MGPII them. M. Toreza. Linguistic aspects of imagery - M., 1981. - Issue. 174. - P. 112-127. 